\title{
Regional actorness and interregional relations: ASEAN, the EU and
}

\section{Mercosur}

\section{Abstract}

The European Union (EU) has a long tradition of interregional dialogue mechanisms with other regional organisations and is using these relations to project its own model of institutionalised actorness. This is partly motivated by the emerging actorness of the EU itself, which benefits from fostering capable regional counterparts in other parts of the world. This article advances the argument that actorness, which we conceptualise in terms of institutions, recognition and identity, is a relational concept, dependent on context and perception.

Taking the Association of Southeast Asian Nations (ASEAN) and the Common Market of the South (Mercosur) and their relations with the EU as case studies, this article demonstrates that the actorness capabilities of all three organisations have been enhanced as result of ASEAN-EU and Mercosur-EU relations. However, there are clear limits to the development of the three components of regional actorness and to the interregional relations themselves. These limits stem both from the type of interregionalism at play and from the different regional models the actors incorporate. While there is evidence of institutional enhancement in ASEAN and Mercosur, these formal changes have been grafted on top of firmly entrenched normative underpinnings. Within the regional organisations, interactions with the EU generate centrifugal forces concerning the model to pursue, thus limiting their institutional cohesion and capacity. In addition, group-to- 
group relations have reinforced ASEAN and Mercosur identities in contrast to the EU. The formation of such differences has narrowed the scope of EU interregionalism despite the initial success of improved regional actorness.

\section{Keywords}

Actorness, interregionalism, regional organisations, European Union, ASEAN, Mercosur

\section{Introduction}

Recent years have seen an increasing proliferation of scholarship on cohesion and effectiveness of regional organisations as international actors (Delreux, 2014; Oberthür and Groen, 2015; Peters, 2016). Most of this literature focuses on the European Union, leaving the evolving actorness of other regional organisations largely under-explored (for exceptions see Wunderlich, 2012; Murau and Spandler, 2016). This article argues that the actorness of the EU itself is ultimately linked to and even dependent on the emergence of so-called "regional others" (Gilson 2005), i.e. regional organisations with actorness features. Actorness is a relational concept, not exclusively determined by endogenous factors such as material endowments, but also dependent on context and recognition. This focus on external recognition contributes to explaining the longstanding EU support for the strengthening of the institutional capabilities of other regional organisations. In terms of enhancing EU actorness, interregionalism has two potential advantages. First, the emergence of other regional actors makes the EU less exceptional by overcoming the $n=1$ problem. It normalises the EU and generates greater levels of acceptance in global governance forums by creating comparable 
'others'. And second, it generates a platform for mutual recognition and interaction between the EU and other regional organisations.

This article takes EU-ASEAN and EU-Mercosur relations as its focal point. These relations rank very high for all three parties involved and play a central role in Europe-Asia and Europe-South America interregionalism at large. In addition, and central to the concept of actorness, Mercosur and ASEAN have remained autonomous despite strong links with the EU, unlike most African regionalisms such as the African Union, which are financially dependent on the EU (Haastrup, 2013; Engel, 2015). In both our cases, there is evidence that the EU has actively engaged in transferring its own model of institutional actorness, a point well made by the diffusion literature (Börzel and Risse, 2009, 2012; Jetschke and Murray, 2012). However, while the actorness capabilities of all partners involved have been enhanced as result of these dialogue mechanisms, there are also clear limits. Our argument is that this can be explained by the inherent dynamics of interregional group-to-group relations and the resulting implications for the components of regional actorness.

The article will proceed in the following manner. The first section of this article reviews the most important scholarly contributions to our understanding of regional actorness and interregionalism. From this emerges a conceptual component-based actorness framework that will guide the case studies of the second section.

\section{Regional actorness and interregionalism}


This section reviews the literature on actorness and the linkages between interregionalism and regional actorness. Actorness in world politics is the result of a multitude of interactions. It is contextual, inter-subjective and relational and does not require the sovereign authority, decision-making powers and foreign policy instruments that characterise statehood. The actorness concept evolved as a deliberate attempt to move beyond methodological nationalism to account for the international activities of the European Community (Murau and Spandler, 2015: 931). ${ }^{1}$ Regional organisations, such as the European Community, are constituted of states and often lack real autonomy. And yet, the actorness concept holds that such entities can be more than just the sum of their parts. As social constructs international actors are established and consolidated through practices, discourses and institution-building (Hettne, 2014; van Langenhove, 2011). This involves the framing and positioning of a regional organisation as a relevant actor in a particular relational context such as group-togroup relations.

The literature on regional actorness can be traced back to the 1970s (Cosgrove and Twitchett, 1970), especially to Sjöstedt's definition as the ability of an entity to engage in international relations (1977: 16). More recently, actorness has been defined as the capacity to "develop presence, to become identifiable, aggregate interests, formulate goals and policies, make and implement decisions" (Rüland, 2002: 6). The development of component-based approaches by Jupille and Carporaso (1998) and Bretherton and Vogler (1999) count as particular milestones in the literature. The actorness framework we adopt has evolved from this tradition and is based on three components: institutions, recognition and identity (see also

\footnotetext{
1 'Methodological nationalism' refers to the notion that the state is the only relevant actor in international relations (Söderbaum, 2016: 53).
} 
Wunderlich, 2012; Doidge, 2014; Hettne, 2014). It therefore combines institutionalist arguments with constructivist insights, as will be outlined in the remainder of this section. Institutions are key components of actorness (Jupille and Caporaso, 1998; Bretherton and Vogler, 1999; Doidge, 2007). Understood as sets of formal and informal norms, rules and principles (Kjær, 2004: 8), they directly impact on visibility, capacity, and cohesion here defined as the ability to formulate a coherent position and to represent it at the international level (Delreux, 2014: 1021). Formalised institutions and decision-making structures enhance cohesion. This can be more challenging for informal institutions characterised by a preference for convention and mutual understanding rather than legal rules and competencies. Such institutions are more prone to volatility, which potentially undermines the ability of an organisation to speak with one voice on a particular issue.

Recognition emerges as another core condition not only for interaction but also for identification as a relevant actor in a particular context (Bretherton and Vogler, 1999). It can be defined as acceptance by other actors in the international system (Delreux, 2014: 1018). International organisations may have struggled in the past to be recognised as negotiation partners in international relations. Yet, this is not necessarily the case anymore: Participation in global governance forums as well as relations with other actors regularly confer de jure and de facto recognition to regional organisations and other non-state actors.

Several scholars have noted the importance of inter-subjective aspects of identity for actorness ( Hettne, 2011, 2014; Doidge, 2007; Wunderlich, 2012; Söderbaum, 2016). It is a social category that is informed by constitutive norms (formal and informal rules), social purposes (shared goals), relational comparisons (defining group identity by what it is not, i.e. 
against the 'other') and cognitive models (background worldviews and common understanding of political and material conditions) (Abdelal et al., 2006: 696). Indeed, the normative and ideational foundations of a regional organisation define its institutional culture. They support a 'meta-regime' - a system of rules, procedures, and actions, rooted in the self-understanding and identity of a regional organisation (Aggarwal and Chow, 2010). Relations between the EU and other regions impact on all three actorness components. They encompass political, cultural, social and security cooperation, as well as trade and aid relations and go far beyond the structured group-to-group relations, which are the main focus of this article (Söderbaum et al., 2005; Ponjaert, 2013). Group-to-group relations are a way of transforming a subject-object relationship into a subject-subject relationship (Gilson, 2005; Hänggi, 2003). They can be regarded as a series of overlapping processes whereby regional organisations create a platform for mutual interaction, attaining international presence and recognition in the process. It is important that this is not a one-time event. The emphasis is on continuous mutual recognition and interaction in order to cement actorness. Hence, enhancing the actorness of other regional organisations is woven into the EU's desire to be recognised as an actor itself. This can take the form of supporting regional organisations elsewhere via capacity-building or of the export and projection of its own institutional and normative preferences (Manners, 2002; Börzel and Risse, 2012). Alternatively, it can occur as the result of institutional copying, with or without an active role of the EU. These issues will be discussed in some more detail below, focusing first on EC/EU-ASEAN relations followed by EU-Mercosur relations. 


\section{Interregionalism and regional actorness}

\section{EU-ASEAN relations}

ASEAN emerged in 1967 in a post-colonial and Cold War context and was designed to cement the sovereignty of its member-states. ${ }^{2}$ The EC became the first regional dialogue partner of ASEAN as early as 1972 (EU Delegation in Jakarta, 2013: 1). The relationship was formalised with the first ASEAN-EC Ministerial Meeting (AEMM) in 1978 and the ASEANEC Cooperation Agreement in Kuala Lumpur of 1980 (ASEAN, 1980). Initially, the relationship was primarily driven by economic imperatives. However, during the 1990s the economic intensified and acquired. The Maastricht Treaty transformed European integration by creating the EU, enhancing institutional cohesion, adding new policy areas and paving the way for enlargement. Meanwhile, Southeast Asia had emerged as a political and economic region to be reckoned with. ASEAN economies experienced a period of high and sustained economic growth between 1987 and 1997, averaging a GDP growth of 7.4\% per year. ${ }^{3}$ There were moves towards closer economic integration as evidenced by the AFTA proposal (ASEAN Free Trade Agreement) (ASEAN 1992). Reacting to the new economic realities, the European Commission called for increased cooperation with ASEAN (European Commission, 1996a). However, the 1997/98 Asian financial crisis undermined the economic attractiveness of Southeast Asia.

\footnotetext{
2 The ASEAN Declaration of 1967 was signed by Malaysia, Singapore, Indonesia, the Philippines and Thailand. ${ }^{3}$ GDP change at constant prices (IMF, 2012).
} 
Recent years have witnessed a quantitative increase in the number of ASEAN-EU meetings, summits and declarations. Since 2007, several summits, meetings and action plans declared the mutual desire to renew and strengthen the ASEAN-EU dialogue, building solid regional organisations, moving beyond trade to collaborate more on political-security and sociocultural issues (Khandekar, 2014: 7). ${ }^{4}$ The EU signed ASEAN's Treaty of Amity and Cooperation (TAC). In part, this is a reflection of Southeast Asia's economic recovery but also ASEAN's post-crisis institutional reforms and its enhanced actorness.

From early on, the ASEAN-EC/EU dialogue mechanism generated a platform for mutual recognition, presence and interaction for both organisations - the 1980 Kuala Lumpur agreement specifically refers to ASEAN as a "viable and cohesive grouping" (ASEAN 1980). Conversely, relations with ASEAN also supported the nascent European Political Cooperation (EPC) providing an opportunity for the EC to be recognised as an actor in its own right (Regelsberger, 1990: 11). The ASEAN grouping was identified as a key economic and political partner for the EU (European Commission, 2001: 21). This worked both ways as the dialogue also helped to enhance EU visibility, recognition and presence in Southeast Asia and beyond (European Commission, 2003).

The principle norms and values that underpin ASEAN institutions are defined by the ASEAN way. This leads to a 'soft' organisational approach based on consensus-based decisionmaking and legally non-binding arrangements. ASEAN's procedural norms are convention, voluntarism and informal agreement. As a consequence, ASEAN has traditionally lacked in cohesion, finding it difficult to pursue goals and objectives as a group, relying "on the

\footnotetext{
${ }^{4}$ In 2012, the Bandar Seri Begawan Plan of Action 2013-2017 was signed at the $19^{\text {th }}$ AEMM, further deepening interregional relations and cooperation on economic but also political and security issues.
} 
collective will of its member states, their perceived national interests, and peer pressure to ensure compliance with its agreements and decisions" (Asian Development Bank, 2010: 125). This has put constraints on ASEAN's institutionalisation and actorness.

The EC/ EU has directly and indirectly impacted on ASEAN's institutional structure by offering declaratory and material support through capacity-building measures such as the Institutional Development Programme for the ASEAN Secretariat (IDPAS), the ASEAN Programme for Regional Integration Support (APRIS and APRIS II) and the current ASEAN Regional Integration Support from the EU (ARISE). ${ }^{5}$ More indirectly, European integration functioned as a model (Hwee, 2008; Jetschke, 2009). When the Asian financial crisis raised questions about ASEAN's credibility, ASEAN responded with the Chiang Mai currency swap initiative which was "stimulated by the system of the EMU in Europe" (Gilson, 2004: 197) and by enhancing institutional cohesion. The outcome has been the 2007 ASEAN Charter, which "heavily emulates EU concepts and terminology" (Börzel and Risse, 2009: 13). The Charter provides ASEAN with legal personality and a three-pillar structurepointing to the EU's Maastricht Treaty as a template (Moxon-Brown and Murray, 2013: 523). Furthermore, the Charter establishes the ASEAN Summit, comprising the heads of state of the members, as the supreme institutional body of the Association. Subordinated is the ASEAN Coordinating Council, made up of ASEAN foreign ministers, which is charged with preparing the summit meetings and to coordinate the implementation of summit decisions. This summit structure and the Committee of Permanent Representatives have invited comparison with the EU and itsCommittee of Permanent Representatives (COREPER)

\footnotetext{
${ }^{5}$ See also the work of Jetschke and Murray (2012).
} 
(Moxon-Brown and Murray, 2013). Importantly, the ASEAN Charter has enhanced the resources of the ASEAN Secretariat and created the post of ASEAN Secretary-General who, among other things, "presents the views of ASEAN and participate in meetings with external parties" (ASEAN 2007). In short the ASEAN Charter represents a concerted effort to enhance institutional cohesion by becoming a more rule-based organisation including a commitment to legally binding obligations. It certainly “improves the organization's compliance mechanisms, streamlines its decision-making structure, and extends its disputesettlement mechanism" (Asian Development Bank, 2010: 124).

However, at a second glance the institutionalised actorness of ASEAN remains limited.. In terms of actorness, ASEAN has created institutions that are empty shells - making it a 'hollow actor' akin to a Potemkin village. ASEAN's representation in global governance institutions such as the UN, for example, remains marked by its weak organizational capacity, limiting its effectiveness as an actor. The ASEAN Charter strengthened ASEAN institutions on paper, but this has not been "matched by a commensurate increase in the annual budget for the ASEAN Secretariat, or any substantive adjustments in financial contributions from ASEAN members to the organization" (Chin, 2009: 32). The resources of the ASEAN Secretariat remain modest, especially when compared to the European Commission. In 2012, its annual budget amounted to approximately US\$16m (Chongkittavorn, 2012). It has no executive and legislative powers. Crucially, the ASEAN Charter also enshrines the ASEAN way as the normative and ideational core of the Association. Institutions have been crafted on top of pre-existing ideational underpinnings, which remain sovereignty-centric.

This ideational core can be traced back to ASEAN's foundational rationale to create an environment conducive to state-building by "promoting regional peace and stability" 
(ASEAN, 1967). This common purpose is expressed in the so-called ASEAN way, a set of constitutive norms centred on the non-use of force in intra-regional disputes, non-interference and regional autonomy (Acharya, 2009; Haacke, 2003). ${ }^{6}$ It has created a web of norms into which ASEAN's members are sought to be socialized (Jones, 2010: 480) and which informs not only the self-understanding of the ASEAN grouping but also shapes its mode of institutionalisation. ASEAN's identity has continuously evolved through its international relations and interactions. The resurgence and increasing proliferation of regional arrangements in the 1990s has also led to a new level of interregional relations such as the Asia-Europe Meeting (ASEM) (Baert et al., 2014: 4). Through ASEM, the EU and ASEAN have both gained in recognition and visibility. For example, the Commission participates alongside its member-states positioning itself and, by extension, the EU, as a relevant actor within ASEM. ASEM has also helped to further the notion of ASEAN actorness through a series of coordinating mechanisms whereby ASEAN members frequently act as a group (Stubbs, 2002: 442). And, like the Commission, the participation of the ASEAN Secretariat within ASEM reinforces the notion of ASEAN as an international actor.

In the post-Cold War era the EU has placed an increasingly high priority on norms associated with good governance, human rights and market economy in its external relations (Manners, 2002). This 'awakening' of EU normative power offered potential for conflict with ASEAN for whose member-states democracy and human rights played, at best, a marginal role. There is a strong correlation between the EU's more active dissemination of its normative priorities within the context of ASEAN-EU relations and norm reinforcement in ASEAN, for example,

\footnotetext{
${ }^{6}$ See also ASEAN $(1967,1976)$.
} 
in the form of the 'Asian values' debate. ${ }^{7}$ As a result, the ASEAN way with its emphasis on sovereignty and non-interference has become further entrenched. This can be seen with the ASEAN Charter enshrining the ASEAN way as foundational principle of the ASEAN community, thereby limiting any institutional innovation.

To summarise, group-to-group relations have indeed impacted on, both, EU and ASEAN actorness. Both have gained a platform for mutual interaction and recognition as relevant actors. The EU has also directly and indirectly fostered an upgrading of the institutional component of ASEAN actorness. However, ASEAN institutional structures remain conditioned by the ASEAN way, the core of ASEAN's identity. Enhanced relations with the EU and EU norm promotion since the 1990s have not changed ASEAN's emphasis on sovereignty and non-intervention. If anything, they have helped to accentuate the differences, with the EU providing the explicit 'other' against which ASEAN leaders define the Association. In other words, ASEAN-EU relations are predicated on conflicting processes with regard to actorness enhancement. ASEAN's identity may have been strengthened, however, its constitutive norms place clear limitations on institutional development and, thus, on capacity and cohesion as an actor.

The interregional dialogue mechanism between the EU and ASEAN has clearly impacted on both organisations. ASEAN actorness has been enhanced and limited at the same time. These contradictory trends are, as explained, conditioned by the very components of actorness. They are also the result of inconsistency in the EU's approach to ASEAN. In 2009, negotiations for an EU-ASEAN Free Trade Agreement (FTA) came to a halt, and the EU

\footnotetext{
${ }^{7}$ See Gilson's work on norm reinforcement (2005).
} 
began to pursue bilateral negotiations with individual ASEAN members. An agreement with Singapore was initialled in 2013 and the EU has been negotiating with Malaysia, Vietnam and Thailand (European Commission, 2013). While this enhances the presence and visibility of the EU in the region, it is also sidelining ASEAN as a grouping.

\section{Mercosur-EU relations}

Mercosur was set up in 1991 to promote trade and democracy, and to overcome the rivalry between countries in the Southern cone of South America. Apart from the main axis of Brazil-Argentina it also encompasses Uruguay and Paraguay as founding members as well as Venezuela (2012) and Bolivia (accession in process since 2015). Like ASEAN, Mercosur mainly relies on intergovernmental structures with limited institutional capacity (Malamud, 2015). The Mercosur secretariat receives minimal human and financial resources from its member states, which have furthermore not transferred any meaningful decision-making powers. The main elements of the EU's relationship with Mercosur have broadly fallen into two areas: the promotion of economic exchanges and the support of Mercosur's institutional capacity. This section will analyse the repercussions of both areas on the three actorness elements.

The economic pillar of relations between Mercosur and EU dates back to 1995 when a framework agreement was signed with the EU to facilitate trade (European Commission, 1996b: 4-22). By then, the EU already was the largest investor and trade partner for the region, thus providing a functional motive to formalise relations. However, Mercosur had 
been conceived by its members as a means to converge with the US-led North American Free Trade Agreement (NAFTA) into a hemispheric Free Trade Area of the Americas (FTAA) (Botto and Bianculli, 2011: 91). The EU was perceived as an old-fashioned and sui generis model while NAFTA, much like ASEAN, represented a cost-effective way of addressing the challenges of globalisation through trade liberalisation (Senti, 1997).

During the second half of the 1990s, economic and financial crises spread throughout the region and Mercosur countries became increasingly critical of trade liberalisation with the US. The FTAA negotiations eventually collapsed in 2005. Argentina abandoned liberal economic paradigms US alignment, while Brazil was keen to pull South America under its own aegis. This opened a window of opportunity for a reorientation towards the EU. However, its Common Agricultural Policy was designed to keep Mercosur's strong agribusiness sector at bay and Mercosur countries were not ready to make wide-ranging concessions for services, intellectual property and manufactured goods (Piketty et al., 2009). Not unlike ASEAN-EU FTA negotiations, EU-Mercosur FTA relations remained characterised by endless negotiation rounds but lacked substantial outcomes. ${ }^{8}$ Mercosur's objective of further institutionalising regional integration via a common market has also not been spurred by the negotiations. Further complicating the actorness of Mercosur has been the so-called strategic partnership between the EU and Brazil (European Commission, 2007a). Even though it was formally supposed to only address issues that are not at the core of Mercosur-EU relations overlaps have been inevitable (Santander, 2014). Alliances with emerging powers such as Brazil who can act as proxies for their regions may yield faster

\footnotetext{
${ }^{8}$ Between 2004 and 2010, the negotiations were suspended due to the unwillingness on both sides to revisit positions on trade. So far, a total of nine negotiations rounds have been held without reaching an agreement.
} 
results but as in Asia it comes at the expense of undermining the EU's ideal of supporting stronger regional institutions.

Recurring disputes between European and Mercosur countries over economic and other issues, such as migration, not only underline the low prospects of a tangible agreement but also point to the role of interregionalism for a regional identity. ${ }^{9}$ The sluggish progress of FTA negotiations reflects the existence of other foreign policy priorities, both for EU and Mercosur members. An increasing perception of otherness was supported by the promotion of South-South relations under the Lula/Dilma and Kirchner/Fernandez de Kirchner governments in Brazil and Argentina. As a consequence, Mercosur, much like ASEAN, reinforced the sense of a regional identity within its own grouping as well as a Global South identity as an alternative to the unsatisfying relationship with the EU. Conversely, the negotiations with the EU, however tedious, have also paved the way for Mercosur to gain recognition as an economic bloc and thus become a contiguous actor for third parties. As a consequence, from the early 2000s on Mercosur negotiated and signed agreements with new partners in the Global South, such as the Southern African Customs Union, India and Morocco.

The second pillar of Mercosur-EU relations constitutes the EU's support to Mercosur's institutional structures. Technical support was initiated right at the beginning and capacitybuilding was formalised with the Inter-Institutional Cooperation Agreement in 1992 and other institutional and technical cooperation programmes (Doidge, 2014: 50). In the last funding period from 2007 to 2013, EU administrative aid to Mercosur amounted to 50

\footnotetext{
${ }^{9}$ In 2012 for example, the diplomatic disputes between the EU and Argentina arose after the nationalisation of a Spanish oil subsidiary.
} 
million euros (European Commission, 2007b). From the EU's perspective, the money would ideally go to setting up Mercosur as a regional peer and follower, including a centralised bureaucracy and communitarian institutions. Accordingly, an important aspect was to cover expenses related to the initialisation of integrative structures, such as the Mercosur Secretariat, the Permanent Appeal Court and the Mercosur Parliament (also known as Parlasur). While Mercosur members agreed in principle to these central bodies, their general scepticism of ceding national sovereignty to autonomous or even supranational regional institutions remained deeply engrained (Gómez-Mera, 2013; Lenz, 2012). The divergence over institutionalisation also reflects a gap in the aspired regional models to handle issues such as the free movement of goods and people (Acosta and Geddes, 2014). Eventually, the plans of the EU to strengthen the Secretariat and the Court were rejected by Mercosur members.

Support to the Mercosur Parliament was maintained from 2007 to 2010 with a budget of two million euros. However, the money was not absorbed and following a mid-term evaluation of the programme, funding for institution-building was entirely discontinued. Progress to establish the Mercosur Parliament was deemed "unsatisfactory, as a substantial share of the activities were not implemented (sic)" (European Commission, 2010: 16). The remaining funds were redirected towards regional projects rather than institutions. These new projects had a functional and thematically confined scope and they were mainly carried out by national agencies. They typically included the facilitation of cross-border cooperation in fields ranging from energy to tourism. The resistance of Mercosur governments to create autonomous regional institutions, even if funding and financial incentives are available, demonstrates that the EU model of institutionalisation does not easily travel. 
As in ASEAN, institutions partly bear a resemblance to their EU counterparts, especially the Mercosur Parliament and Court but also its Economic Convergence Fund (FOCEM) (Dri, 2011: 261). These three bodies constitute a remarkable compromise between European ideas and South American policies. They have considerable supranational potential but lack autonomous regional authority concerning decision-making or implementation.

The Court and the Parliament have few competences over legislative and juridical matters. Unlike the European Court of Justice, Mercosur's Court is not backed by communitarian law and has only dealt with a small number of cases (Franca Filho et al., 2010; Malamud, 2015: 173). The members of the Parliament are mainly a sample of national deputies meeting sporadically over the course of the year (Malamud and Dri, 2013). ${ }^{10}$ The case of FOCEM further illustrates how function does not follow form. Most projects financed by FOCEM are not designed with a regional scope, as they lack cross-border components. ${ }^{11}$ Brazil has provided the bulk of the budget ${ }^{12}$ and used FOCEM as part of a patronage network to provide rewards that ensure the alignment of the smaller members with Mercosur policies designed by Brazil, especially concerning interregional negotiations (Mattheis, 2014). ${ }^{13}$

\footnotetext{
${ }^{10}$ Paraguay was the first member to hold direct elections in 2008. The other states were scheduled to follow but the implementation has been postponed several times. Only Argentina held the first elections for the Mercosur Parliament simultaneously with general elections in October 2015.

${ }^{11}$ The financing mainly goes to local infrastructure or social expenditures.

${ }^{12}$ For 2013, Brazil contributed over $80 \%$ to the budget while almost $90 \%$ of the funds were intended to go to Paraguay and Uruguay (Mercosur, 2012). However, the current domestic budget crisis could reduce the financial leverage of Brazil.

${ }^{13}$ Uruguay is the country with the highest income per capita in the region and is therefore less in need of financial support to catch up with the region but it remains a major recipient. Brazil is bound to negotiate trade agreements within Mercosur and requires Uruguay's endorsement for its global trade ambitions. Uruguayan perception of power asymmetries in favour of Brazil have led to discontent and threats to leave Mercosur for closer alignment with the US.
} 
EU support to Mercosur's capacity naturally puts the institutional component of actorness into the limelight. Mercosur having incorporated emblematic elements from the EU underlines the importance of the latter's repertoire of formalised and institutionalised models. However, it has only adopted elements that are neither legally binding nor reflect supranational characteristics. The "institutional mimesis of the EU" (Dri, 2011: 259) has produced a shell without the matching content. Mercosur members have resisted the profound legal and structural changes that an all-embracing incorporation of the EU's ideal would require. Similar to most ASEAN member they follow an understanding of stateness which carries strong notions of national sovereignty and postcolonial independence. This normative self-concept is laid down in the countries' constitutions and sets clear boundaries for the appropriation of EU-style institutions and rules.

Despite the limited impact on institution building, the other two actorness categories have been more favourably affected. Regarding recognition, interregionalism has increased the visibility and presence of Mercosur as a grouping at the international and regional level (Doctor, 2015). This highlights Mercosur as a regional project to other countries, in particular to those that are also willing to look at the EU as a reference and supporter. Sharing a paradigm of regional integration provides a common language with other regional organisations. In terms of identity interregionalism with the EU plays a central role, as the self-perception and self-positioning of Mercosur steadily oscillate between alignment and antagonism with the EU. Over the years knowledge of the EU has grown considerably in South American universities and political institutions. While North America is by far the most attractive place for higher education (UNESCO, 2014), Europe offers a niche in training future regional policy-makers. The civil servants in charge of regional affairs are likely to be 
guided by examples provided by the EU. The influence of the European model is also reflected in the way South Americans tend to use the EU as a benchmark to measure the level and success of integration in Mercosur (De Lombaerde, Mattheis and Vanfraechem, 2010: 169).

\section{Interregionalism and actorness - an ambivalent relationship}

The EU has invested considerable resources and time in establishing and maintaining relations with both ASEAN and Mercosur. This interregionalism has in part been driven by a desire to export its own version of regional actorness. The EU regards itself as the purveyor of certain norms and principles, among them a model of successful regional integration, which might not always reflect reality (Fioramonti and Mattheis, 2016). This outreach is facilitated by the desire of governments in the developing world to enhance their standing and legitimacy by incorporating parts of the institutional structure of the EU into their regional projects (Börzel and Risse, 2009: 9).

Interregional dialogue has created a space for all three groupings to interact, to recognise each other and to be recognised - in short, to be actors. ASEAN-EC/EU and Mercosur-EU relations can look back at several decades, making it a good opportunity to take stock how it has affected the regional projects. Our two case studies highlighted the ambiguities of the mutual influence between interregionalism and the three different elements of actorness.

In terms of institutionalisation, we find that interregionalism has produced approximation but also resistance. There is evidence of echoing in both cases: ASEAN and Mercosur have 
acquired elements of actorness and relations with the EU having played an important role in this process. The EU has directly and indirectly supported institutional capacity-building measures, thereby aiming to explicitly position itself and its partners as international actors. Furthermore, the asymmetrical nature of EU interregionalism has fostered institutional learning and socialisation in both relationships (Doidge, 2014). The same asymmetry also strengthened ASEAN and Mercosur group cohesion. Faced with a more institutionalised and more coherent partner, ASEAN and Mercosur members were incentivised to work more closely together. For example, it pushed ASEAN to enhanced coordination and cohesion prior to ASEM summits (Fitriani, 2014: 50). However, ASEAN and Mercosur seem to only superficially mimic the institutional structure of the EU in order to gain international recognition (Jetschke, 2009; Dri, 2011). Indeed, interregional relations with the EU have very much helped to accentuate and to entrench a normative core that sets limits to institutional capacity in both ASEAN and Mercosur. In turn, the EU's institutionalisation has also been consolidated. Interregionalism has given the EU a continuous task to perform and to professionalise with considerable autonomy. This has sustained a leadership role of regional institutions over member-states.

There is also evidence that identity-building has happened, for example through relational comparison and norm reinforcement. Mercosur and EU's divergent approaches to trade and migration regimes, the conflicts between the EU and ASEAN over Myanmar or East Timor and the entrenchment of the ASEAN way in the ASEAN Charter are indicative of this. Processes of repeated interaction with the regional 'other' help to shape the ideational consciousness and sharpen perceptions of difference and 'us'. Interregionalism, therefore, can lead to the ideational positioning of difference as for instance, in the case of ASEAN, through 
'Asian values' or the Beijing Consensus (Rüland, 2012: 257). Thus, while the EU has aimed to strengthen the organisational capacity of ASEAN and Mercosur, EU-ASEAN and EUMercosur relations have inadvertently enhanced diverging ASEAN and Mercosur identities, reinforcing constitutive norms that have limited institutional cohesion in the first place. The EU's identity has also been strengthened through these relations by reinforcing the notion of EU norms and interests to be fostered abroad.

Lastly, in terms of recognition, the EU's motivation to engage with Mercosur and ASEAN is twofold. First, it is enhancing its own standing as an international actor not only within Southeast Asia and Latin America but also globally. EU actorness partly relies on the existence of regional organisations modelled along similar institutional lines. The EU thus creates platforms for interactions between regional actors for the purpose of strengthening recognition and presence on both sides. The second motivation is the EU's normative commitment that functioning regional institutions facilitate peace and prosperity. Importantly, this also includes a belief in a duty to actively export its own institutional model in order to positively influence the global order (Hettne, 2007). In turn, Mercosur and ASEAN partly mimic EU norms and institutions, not only because they are globally regarded as the most advanced model of regional actorness but also thanks to the exposure to and creation of knowledge of European integration. EU-style institutions confer prestige and credibility, especially when dealing with the EU itself. Through interregionalism both sides are also able to gain recognition by third parties.EU interregionalism with ASEAN and Mercosur has thus yielded very modest results in terms of institutionalised actorness, and the EU has recognised the limitations of this strategy. Following the disappointing evolution of its funding programme, support to Mercosur was discontinued altogether in 2013 (Europe 
Direct, 2015). Yet, abandoning the support for regionalism in general is hard to reconcile with how the EU sees itself and would like its partners to develop, especially since its own actorness benefits from interregionalism. Consequently, under the new Latin America programme Central America is still eligible for regional integration support despite the frustrations with Mercosur (European Commission, 2014a, 2014b). This perspective, however, may overemphasise the actorness of the EU itself. Rather than being a monolithic actor, the EU, like ASEAN and Mercosur, can be understood as a "composite international actor" (Santander, 2014). The EU employs a diverse set of interregional relations which can be directed at states or regional organisations, issue-specific or multipurpose, and can link to global governance and multilateral structures. This picture is further complicated by the division of external competencies within the EU between different EU institutions and member-states. Thus, it is difficult to discern a common rationale underlying the various interregional contacts. They are based on different foundations, reflecting the nature of the regional states or groupings involved as well as the interest of the various actors lurking below EU level such as the Commission, the European Parliament, foreign ministries or lobby groups to name but a few (Fahey, 2016). In Latin America and South-East Asia the lack of supranational bodies reduces the number of actors but much diversity remains due to the high number of regional projects and coalitions, though many are only temporary.

Whether EU interregionalism has failed to strengthen ASEAN and Mercosur actorness depends on perspective and expectations. Mercosur and ASEAN have enhanced their institutional structures and have gained in recognition and presence not least within their own regional context vis-a-vis competing projects. Interregionalism has also enhanced the identity consciousness of ASEAN and Mercosur, which ultimately determines form and function of 
institutionalisation. Interregionalism provides several opportunities to improve regional actorness but the ambitious expectations that have been associated with the engagements of the EU deserve to be met with caution. The EU still engages with Mercosur and ASEAN and both, in turn, are periodically turning to the EU for ideas and support but each attempt at interregionalism also exposes and accentuates differences. In sum, our research shows that interregionalism has an identifiable, though limited, impact on regional actorness. However, this should not be mistaken for a global alignment of the regional organisations. Instead, interregional exposure is encouraging the formation of discrete identities and institutions.

Brexit and Donald Trump's election as US president are indicative for political populism and economic nationalism that are challenging the liberal consensus across the world. This puts pressure on regional organisations such as the EU and challenges its main mode of interregionalism. The EU has already championed strategic partnerships with key states in specific regions around the globe. Such bilateral links between the EU as a region and individual countries could become an even more important template in the years ahead, not least to accommodate the UK and the US outside of a multilateral framework. However, interregionalism is likely to remain important thanks to its adaptable nature. It goes well beyond the relations between formal institutions, be that states or regional organisations. Far from being a static concept, interregionalism can include a much wider array of actors and structures than are the focus of this study. Further research on the EU's interregionalism needs to tackle the multiplex, porous and dynamic nature of regions in order to assess the whole range of connections between them. 


\section{References}

Abdelal R, Herrera YM, Johnston AI and McDermott R (2006) Identity as a Variable. Perspectives on politics 4(4), pp.695-711.

Acharya A (2009) Whose Ideas Matter? Agency and Power in Asian Regionalism. Ithaca: Cornell University Press.

Acosta D and Geddes A (2014) Transnational Diffusion or Different Models? Regional Approaches to Migration Governance in the European Union and Mercosur. European Journal of Migration and Law 16, pp.19-44.

Aggarwal VK and Chow JT (2010) The Perils of Consensus: How ASEAN's Meta-Regime undermines Economic and Environmental Cooperation. Review of International Political Economy 17(2), pp.262-90.

ASEAN (1967) The ASEAN Declaration (Bangkok Declaration). 8 August. Available at: <http://www.asean.org/news/item/the-asean-declaration-bangkok-declaration> (accessed 2 September 2015).

ASEAN (1976) Treaty of Amity and Cooperation in Southeast Asia. 24 February. Available at: <http://www.asean.org/news/item/treaty-of-amity-and-cooperation-in-southeastasia-indonesia-24-february-1976-3> (accessed 2 September 2015).

ASEAN (1980) Cooperation Agreement between the Member Countries of ASEAN and the European Community. 7 March. Available at: $<\underline{\text { http://www.asean.org/news/item/external-relations-european-union-nuremberg- }}$ 
declaration-on-an-eu-asean-enhanced-partnership-nuremberg-germany-15-march2007> (accessed 2 September 2015).

ASEAN (1992) Singapore Declaration of 1992. 28 January. Available at:

<http://www.asean.org/news/item/singapore-declaration-of-1992-singapore-28-january$\underline{1992>}$ (accessed 2 September 2015).

ASEAN (2007) The ASEAN Charter. Available at: $<$ http://www.asean.org/archive/publications/ASEAN-Charter.pdf $>$ (accessed 4 September 2015).

Asian Development Bank (2010) Institutions for Regional Integration: Toward an Asian Economic Community. Manila: Asian Development Bank.

Baert F, Scaramagli T and Söderbaum F (2014) Introduction: Intersecting Interregionalism. In: Baert F, Scaramagli T and Söderbaum F (eds) Intersecting Interregionalism: Regions, Global Governance and the EU. Dordrecht: Springer, pp.55-70.

Börzel T and Risse T (2009) Diffusing (Inter-) Regionalism - The EU as a Model of Regional Integration. Working Paper Series of the Research College "The Transformative Power of Europe” (7).

Börzel T and Risse T (2012) From Europeanisation to Diffusion: Introduction. West European Politics 35(1), pp.1-19.

Botto M and Bianculli A (2011) Comparative Asymmetric Trade Negotiations in the Southern Cone: FTAA and EU-Mercosur. In: De Lombaerde P and Tussie D (eds) Asymmetric Trade Negotiations. Farnham: Ashgate, pp.89-116. 
Bretherton C and Vogler J (1999) The European Union as a Global Actor. London: Routledge.

Chin KW (2009) Emerging East Asian Regional Architecture: ASEAN Perspectives. In: Tow WT and Chin KW (eds) ASEAN-India-Australia: Towards Closer Engagement in a New Asia. Singapore: Institute of Southeast Asian Studies, pp.22-39.

Chongkittavorn, K (2012) ASEAN Secretariat must be empowered. In: The Nation. Available at: <http://www.nationmultimedia.com/opinion/Asean-Secretariat-must-beempowered-30182419.html> (accessed 27 June 2016).

Cosgrove CA and Twitchett KJ (1970) The New International Actors - The United Nations and the European Economic Community. London: Macmillan.

De Lombaerde P, Mattheis F. and Vanfraechem C (2010) Mercosur Compared. In: Franca Filho MT, Lixinski L and Olmos Giupponi MB (eds) The Law of Mercosur. Oxford: Hart, pp.165-190.

Delreux T (2014) EU actorness, cohesiveness and effectiveness in environmental affairs. Journal of European Public Policy 21(7), pp.1017-1032.

Doctor M (2015) Interregionalism's impact on regional integration in developing countries: the case of Mercosur. Journal of European Public Policy 22(7), pp.967-984.

Doidge M (2007) Joined at the hip: regionalism and interregionalism. Journal of European Integration 29(2), pp.229-248. 
Doidge M (2014) Interregionalism and the European Union: conceptualizing group-to-group relations. In: Baert F, Scaramagli T and Söderbaum F (eds) Intersecting Interregionalism. Dordrecht: Springer, pp.37-54.

Dri C (2011) The European Union and Latin America. In: Wunderlich J-U and Bailey DJ (eds) The European Union and Global Governance - A Handbook. London: Routledge, pp.254-263.

Engel U (2015) The African Union finances - How does it work? Working Paper Series of the Centre for Area Studies (6). Leipzig: Leipziger Universitätsverlag.

EU Delegation in Jakarta (2013) EU-ASEAN: Natural Partners, $7^{\text {th }}$ edition. Available at:

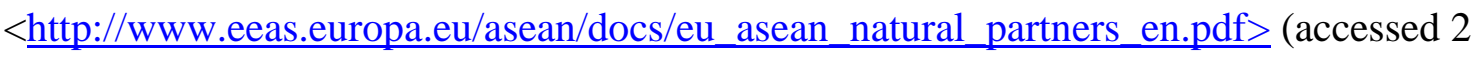
September 2015).

Europe Direct (2015) EU-Mercosur cooperation. Email message to the author. Brussels: European Commission.

European Commission (1996a) Press Release. Available at: <http://europa.eu/rapid/pressrelease_IP-96-580_en.htm> (accessed 2 September 2015).

European Commission (1996b) Interregional Framework Cooperation Agreement: Joint Declaration on political dialogue between the European Union and Mercosur. OJ L 69, pp.4-22.

European Commission (2001) Europe and Asia: A Strategic Framework for Enhanced Partnerships. COM2001(469). Available at: 〈http://eur-lex.europa.eu/legalcontent/EN/TXT/PDF/?uri=CELEX:52001DC0469\&from=EN> (accessed 2 September 2015). 
European Commission (2003) A New Partnership with Southeast Asia. COM2003(399/4). Available at: 〈http://trade.ec.europa.eu/doclib/docs/2004/july/tradoc_116277.pdf> (accessed 4 September 2015)

European Commission (2007a) Towards an EU-Brazil Strategic Partnership: Communication from the Commission to the European Parliament and the Council. COM2007(0281).

European Commission (2007b) Mercosur-Regional Strategy Paper 2007-2013. E2007(1640).

European Commission (2013) The EU's bilateral trade and investment agreements - where are we? Memo. Available at: 〈http://trade.ec.europa.eu/doclib/docs/2012/november/tradoc_150129.pdf〉 (accessed 11 September 2015).

European Commission (2014a) Multiannual Indicative Programme for Latin America: Development Cooperation Instrument 2014-2020. Available at: <http://eeas.europa.eu/la/docs/mip_alr_vf_07_08_14_en.pdf> (accessed 20 September 2015).

European Commission (2014b) The EU allocates $€ 925$ million to regional cooperation with Latin America over the period 2014-2020. Available at: $<$ http://eeas.europa.eu/lac/docs/141105-visibility-event_en.pdf > (accessed 20 September 2015).

Fahey E (2016) The Actors of Postnational Rule-Making - Contemporary Challenges of European and International Law. Oxon: Routledge. 
Fioramonti L and Mattheis F (2016) Is Africa really following Europe? An integrated framework for comparative regionalism. Journal of Common Market Studies 54(3), pp.674-690.

Fitriani E (2014) Southeast Asians and the Asia-Europe Meeting (ASEM) - State's Interests and Institution's Longevity. Singapore: Institute of Southeast Asian Studies.

Franca Filho MT, Lixinski L and Olmos Giupponi MB (eds) (2010) The Law of Mercosur. Oxford: Hart.

Gilson J (2004) Trade Relations between Europe and East Asia. Asia Europe Journal 2(2), pp.185-200.

Gilson J (2005) New Interregionalism? EU and East Asia. Journal of European Integration 27(3), pp.307-326.

Gómez-Mera L (2013) Power and regionalism in Latin America: The politics of Mercosur. Notre Dame: University of Notre Dame Press.

Haacke J (2003) ASEAN's Quiet Diplomatic and Security Culture - Origins, Development and Prospects. London: Routledge.

Haastrup H (2013) EU as Mentor? Promoting Regionalism as External Relations Practice in EU-Africa Relations. Journal of European Integration 35(7), pp.785-800.

Hänggi H (2003) Regionalism through Interregionalism: East Asia and ASEM. In: Liu F-K and Régnier P (eds) Regionalism in East Asia: Paradigm Shifting? London: Routledge, pp.197-219. 
Hettne B (2007) Interregionalism and World Order: The Diverging EU and US Models. In: Teló M (ed) European Union and New Regionalism - Regional Actors and Global Governance in a Post-Hegemonic Era. Aldershot: Ashgate, pp.107-123.

Hettne B (2011) The European Union as an Emerging Global Actor. In: Wunderlich J-U and Bailey DJ (eds) The European Union and Global Governance - A Handbook. London: Routledge, pp.28-36.

Hettne B (2014) Regional Actorship: A Comparative Approach to Interregionalism. In: Baert F, Scaramagli T and Söderbaum F (eds) Intersecting Interregionalism: Regions, Global Governance and the EU. Dordrecht: Springer, pp.55-70.

Hwee YL (2008) EU-ASEAN Relations and Policy-Learning. In: Balme R and Bridges B (eds) Europe-Asia Relations: Building Multilateralisms. Basingstoke: Palgrave, pp.83102.

IMF (2012) World Economic Outlook Database, April 2012. Available at: 〈www.imf.org> (accessed 3 August 2015).

Jetschke A (2009) Institutionalizing ASEAN: Celebrating Europe through Network Governance. Cambridge Review of International Affairs 22(3), pp.407-426.

Jetschke A and Murray P (2012) Diffusing Regional Integration: The EU and Southeast Asia. West European Politics 35(1), pp.174-191.

Jupille J and Caporaso J (1998) States, Agency and Rules: The EU in Global Environmental Politics. In: Rhodes C (ed) The European Union in the World Community. London: Lynne Rienner, pp.213-229. 
Khandekar G (2014) Mapping EU-ASEAN Relations. Madrid: FRIDE. Available at: http://fride.org/download/Mapping_EU_ASEAN_Relations.pdf (accessed 4 September 2015).

Kjær AM (2004) Governance. Cambridge: Polity.

Lenz T (2012) Spurred emulation: The EU and regional integration in Mercosur and SADC. West European Politics 35(1), pp.155-173.

Malamud A (2015) Interdependence, leadership and institutionalization: the triple deficit and fading prospects of Mercosur. In: Dosenrode S (ed) Limits to regional integration. Farnham: Ashgate, pp.163-178.

Malamud A and Dri C (2013) Spillover effects and supranational parliaments: The case of Mercosur. Journal of Iberian and Latin American Research 19(2), pp.224-238.

Manners I (2002) Normative Power Europe - A Contradiction in Terms?. Journal of Common Market Studies 40(2), pp.235-258.

Mattheis F (2014) New Regionalisms in the South-SADC and Mercosur in Comparative and Interregional Perspective. Leipzig: Leipziger Universitätsverlag.

Moxon-Browne E and Murry P (2013) The European Union as a Template for Regional Integration? The Case of ASEAN and Its Committee of Representatives. Journal of Common Market Studies 51(3), pp.522-537.

Murau S, Spandler K (2016) EU, US and ASEAN Actorness in G20 Financial PolicyMaking: Bridging the EU Studies-New Regionalism Divide. Journal of Common Market Studies 54(4), pp.928-943. 
Oberthür S, Groen L (2015) The Effectiveness Dimension of the EU's Performance in International Institutions: Toward a More Comprehensive Assessment Framework. Journal of Common Market Studies 53(6), pp. 1319-1335.

Peters I (2016) The European Union's Foreign Policy in Comparative Perspective: Beyond the 'Actorness and Power' Debate. Oxon: Routledge.

Piketty MG, Weissleder L, Souza Filho HM, Batalha MO and Adenäuer M (2009) Assessing agricultural trade policies options with the European Union: A Brazilian perspective. Agricultural economics 40(4), pp.447-457.

Ponjaert F (2013) Inter-regionalism as a coherent and intelligible instrument in the EU foreign policy toolbox: a comparative assessment. In: Telò M and Ponjaert F (eds) The EU's Foreign Policy: What Kind of Power and Diplomatic Action? Farnham: Ashgate, pp.135-158.

Regelsberger E (1990) The Dialogue of the EC/Twelve with Other Regional Groups: A New European Identity in the International System. In: Geoffrey E and Regelsberger E (eds) Europe's Global Links: The European Community and Inter-Regional Cooperation. London: Pinter, pp.3-26.

Rüland J (2002) Inter- and Transregionalism; Remarks on the State of the Art of a New Research Agenda. National Europe Centre Paper (35), Paper prepared for the workshop on Asia-Pacific Studies in Australia and Europe: A Research Agenda for the Future, ANU, 5-6 July.

Rüland J (2012) The Rise of 'Diminished Multilateralism': East Asian and European forum shopping in Global Governance. Asia Europe Journal 9(2-4), pp.255-270. 
Santander S (2014) The impact of the Iberian states on European Union-Latin American interregionalism. In: Baert F, Scaramagli T and Söderbaum F (eds) Intersecting interregionalism: Regions, global governance and the EU. Dordrecht: Springer, pp.107127.

Senti R (1997) NAFTA as a model for free trade areas between economies in different stages of development. Materialien, Working Paper Series of the Institut für Wirtschaftsforschung, ETH Zürich 97(13).

Sjöstedt G (1977) The External Role of the European Community. Farnborough: Saxon House.

Söderbaum F (2016) Rethinking Regionalism. London: Palgrave.

Söderbaum F, Stålgren P and Van Langenhove L (2005) The EU as a Global Actor and the Dynamics of Interregionalism: a Comparative Analysis. European Integration 27(3), pp.365-380.

Stubbs R (2002) ASEAN Plus Three: Emerging East Asian Regionalism? Asian Survey 52(3), pp.440-455.

UNESCO (2014) Global Flow of Tertiary-Level Students. Available at:

<http://www.uis.unesco.org/Education/Pages/international-student-flow-viz.aspx> (accessed 17 September 2015).

Van Langenhove L (2011) Building Regions: The Regionalization of the World Order. Farnham: Ashgate. 
Wunderlich J-U (2012) The EU and Actor Sui Generis? A Comparison of EU and ASEAN Actorness. Journal of Common Market Studies 50(4), pp.653-669. 